Jurnal Konstruksi Hukum | ISSN: 2746-5055

Vol. 2, No. 3, September 2021 Hal. 628-633| Tersedia online di https://www.ejournal.warmadewa.ac.id/index.php/jukonhum

DOI:http://doi.org/10.22225/jkh.2.3.3669.628-633

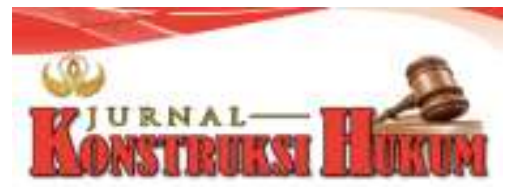

\title{
PERLINDUNGAN HUKUM TERHADAP ANAK KORBAN EKSPLOITASI SEKSUAL BERDASARKAN HUKUM ISLAM
}

\author{
Anak Agaung Mas Stela Kurtikaadi, Anak Agung Sagung Laksmi Dewi \& Ni Made Sukuryati \\ Karma \\ Fakultas Hukum Universitas Warmadewa, Denpasar-Bali, Indonesia \\ stellaakartikaa@gmail.com, laksmidewi29@gmail.com \& madesukaryakarma@gmail.com
}

\begin{abstract}
Abstrak
Anak bangsa yang baik yaitu cerminan dari kualitas yang baik, sehingga perlu dilindungi untuk mendapat wewenang agar bisa tumbuh, berkembang, dan memperoleh kesejahteraan hidup. Tetapi waktu ini perlindungan dan kesejahteraan kepada anak masih sangat kurang, salah satunya persoalan eksploitasi seksual kepada anak hingga jadi kategori kejahatan kemanusiaan yang harus dihindari dan dimusnahkan. Tujuan penelitian ini adalah untuk membahas pengaturan hukum eksploitasi anak termuat dalam hukum islam dan sanksi pidana terhadap pelaku eksploitasi anak menurut hukum Islam. Metode yang digunakan merupakan metode hukum normatif dengan pendekatan masalah perundang-undangan dan konseptual. Hasil pembahasan menyatakan bahwa Eksploitasi yakni wujud upaya yg dilakukan sebagai melaksanakan pendalaman kapasitas yang termuat pada suatu objek, baik itu berbentuk sumber daya alam ataupun lainnya deini relevansi sekelompok/banyak orang, fakto-faktor timbulnya eksploitasi terhadap anak yaitu kemiskinan, efek kondisi sosial, rnotivasi pekerja terhadap keluarga. Sanksi pidana bagi eksploitasi terhadap anak yaitu dalam UU nomor 35 tahun 2014 Pasal 14 ayat (1), Pasal 81 ayat (1) dan pasal 82.
\end{abstract}

kata kunci: Perlindungan Hukum, Anak Korban Eksploitasi,Hukum Islam

\begin{abstract}
A good nation's children are a reflection of good quality, so they need to be protected to get the authority to grow, develop, and obtain a prosperous life. But at this time the protection and welfare of children is still lacking, one of which is the issue of sexual exploitation of children so that it becomes a category of crimes against humanity that must be avoided and destroyed. The purpose of this study is to discuss the legal arrangements for child exploitation contained in Islamic law and criminal sanctions against perpetrators of child exploitation according to Islamic law. The method used is a normative legal method with a statutory and conceptual approach to problems. The results of the discussion state that exploitation is a form of effort carried out to carry out a deepening of the capacity contained in an object, whether it is in the form of natural resources or otherwise, in terms of the relevance of a group/many of people, the factors that cause exploitation of children, namely poverty, effects of social conditions, motivation workers to families. Criminal sanctions for exploitation of children are in Law number 35 of 2014 Article 14 paragraph (1), Article 81 paragraph (1) and Article 82.
\end{abstract}

Keywords: Legal Protection, Child Victims Of Exploitation, Islamic Law

\section{PENDAHULUAN}

Anak merupakan amanah dan anugerah dari Tuhan yang maha Esa yang di dalam dirinya telah melekat harkat dan martabat sebagai manusia seutu hnya. Setiap anak mempunyai harkat dan martabat yang patut dijunjung tinggi sehingga setiap anak yang lahir harus mendapatkan hakhaknya tanpa anak tersebut tanpa meminta. Saat ini masih minimnya perlindungan dan kesejahteraan bagi anak, dan masyarakat tidak tahu apa-apa dan memilih menutup mata (Saraswati, 2015). Perlindungan anak semestinya berpedoman padaupaya yang menjadikan anak sebagai manusia yang patut mendapat perhatian yang baik (Ariyadi, 2019). Persoalan eksploitasi dimasukkan dalam katagori kejahatan kemanusiaan yang harus dihindari dan dimusnahkan, selain kelakuan yang melanggar hukum, melanggar (KHA), juga berdampak pada 
norma agama dan budaya masyarakat beradab. Indonesia sudah mengerjakan berbagai upaya untuk memberantas eksploitasi seksual terhadap anak diantaranya membuat rencana aksi nasional, meratifikasi berbagai instrumen international yang berhubungan dengan perlindungan, dan berbagai aturan khusus ataupun sebagai salah satu bagian buat memberikan keamanan untuk korban eksploitasi seksual. Undang-Undang Nomor 35 tahun 2014 pasal 59 A bentuk dari keamanan aturan untuk anak korban eksploitasi juga tertera di pasal 66. Ajaran islam telah memadu bahwa anak harus dijaga dengan benar, Sebagaimana Allah SWT berfirman pada AlQur'an surat Al-An'am ayat 151.

Permasalahan ini penting untuk dibahas, terbukti pada beberapa penelitian terdahulu yang relevan dengan penelitian ini. Selain melihat permasalahan ini dari perspektif hukum islam, hal ini juga telah diatur dalam hukum di Indonesia. Berdasarkan Undang-Undang Nomor 21 Tahun 2007 tentang pemberantasan tindak pidana perdagangan orang, dimana memberikan perlindungan bagi anak dan memberikan rehabilitasi bagi anak yang menjadi korban eksploitasi anak (Firmansyah \& Suhardini, 2017). Penelitian selanjutnya mengkaji mengenai perlindungan terhadap anak korban eksploitasi seksual dalam perspektif yuridis-Normatif dan psikologis (Permatasari, 2016). Untuk itu perlu adanya reformasi penegakan hukum kekerasan seksual terhadap anak sebagai bentuk perlindungan anak yang berkelanjutan (Arliman, 2017). Penelitian ini kemudian memfokuskan diri untuk melihat permasalahan tersebut berdasarkan perspektif hukum islam. Tujuan penelitian ini adalah untuk membahas pengaturan hukum eksploitasi anak termuat dalam hukum islam dan sanksi pidana terhadap pelaku eksploitasi anak menurut hukum islam.

\section{METODE PENELITIAN}

Penelitian ini menggunakan aturan normatif dengan melakukan pengkajiannya dari bahan-bahan aturan dan cara untuk menemukan prinsip-prinsip maupun doktrin-doktrin hukum untuk menjawab permasalahan yang dihadapi demi membentuk argumentasi, Sedangkan pendekatan masalah yang digunakan yaitu pendekatan konsep hukum dan pendekatan konseptual sebagai cara memecahkan masalah terhadap perlindungan hukum terhadap eksploitasi anak seksual. Berdasarkan hukum islam. Adapun sumber bahan aturan yang dipakai adalah sumber hukum primer dan sekunder yaitu KUHPerdata, UUD 1945 Undang-Undang Nomor 35 tahun 2014. Selain itu juga berpedoman pada buku, jurnal-jurnal serta artikel yang berkaitan dengan perlindungan hukum terhadap anak korban eksploitasi seksual dan hukum islam sebagai permasalahan diatas.

\section{HASIL DAN PEMBAHASAN}

\section{Pengaturan Hukum Eksploitasi Anak Termuat Dalam Hukum Islam.}

Eksploitasi adalah suatu upaya atau kegiatan untuk menggali potensi suatu bentuk untuk secara kolektif (banyak orang) (pemuas kebutuhan), baik berbentu k sumber daya alam ataupun bentuk lainnya. Misalnya perkembangan hutan, perkembangan anak-anak, perkembangan hewan, dll. Menurut Undang-Undang Nomor 4 April 1979 tentang Kesejahteraan Anak, anak yaitu orang yang berusia di bawah 21 tahun dan belum menikah. Eksploitasi anak diartikan sebagai tindakan seenaknya dan perilaku diskriminatif yang diperbuat oleh masyarakat atau keluarga terhadap anak, dengan tujuan memaksa anak menjalankan sesuatu tanpa melihat hak-haknya semacam perkembangan fisik dan mental (Soeaidy \& Zulkhair, 2001)

Eksploitasi Seksual Komersial Anak (ESKA) mengacu pada penggunaan organ seksual anak atau organ lain untuk mendapatkan semua manfaat termasuk prostitusi dan ainoralitas seksual. Keadaan ini dapat dihindari jika pemerintah memberikan perlindungan dan perlindungan bagi anak, terutama anak di bawah umur, supaya mereka dapat hidup sesuai dengan usianya dan memperoleh pendidikan sesuai usianya. Upaya pengembangan bakat yang dijelaskan dalam undang-undang di atas merupakan persiapan psikologis, jadi jangan kaget dengan pekerjaan di masa depan. Di dalam UU No. 35 tahun 2014 beberapa jenis eksploitasi diantaranya:

- Penganiayaan fisik mengacu pada pelecehan pekerja anak untuk kepentingan orang tua atau orang lain, yang dapat menyebabkan terhambatnya perkembangan ernosi. 
- $\quad$ Seks berarti bahwa anak melakukan akt ix'itas seksual yang tidak dia mengerti.

lsu eksploitasi anak telah menjadi perhatian tidak hanya di Indonesia tetapi juga di dunia international. Deklarasi dan Program Aksi Kampanye International untuk Memerangi Eksploitasi Seksual Anak (ESA) telah mencapai puncaknya pada Kongres Dunia melawan ESA yang diadakan di Stockholm pada tahun 1996, Yokohama pada tahun 2001, dan Rio de Janeiro pada tahun 2005. Di Indonesia, ini merupakan fenomena khas dari eksploitasi seksual kepada anak. ECPAT International menjelaskan berbagai alasan yang menyebabkan tindakan ESKA. Salah satunya yaitu anak di bawah umur, korban kekerasan dan penelantaran di rumah. Bagi predator yang cenderung berasal dari lingkungan luar, situasi ini menjadi sasaran empuk. Karnivora menganggap situasi ini sebagai situasi yang tepat untuk memberikan rasa aman kepada anakanak. Berdasarkan DSM IV (1994), kategorisasi gangguan mental masa kanak-kanak meliputi keterbelakangan mental, gangguan perilaku, oposisi abnormal, perhatian dan hiperaktif (deficit perhatian dan gangguan hiperaktif), keterikatan reaktif (gangguan perlekatan reaktifj dan penyakit kecemasan pemisahan (Motosoedirdjo \& Latipun, 2019).

Faktor-faktor yang menyebabkan terjadinya eksploitasi yaitu:

1. Kemiskinan Kemiskinan tarnpaknya menjadi salah satu pemicu utama terjadinya pekerja anak. Untuk mencari nafkah di rumah, banyak anak yang bekerja dari rumah atau bekerja berbayar melakukan ini. Narnun, secara paradoks, pekerja anak juga menjadi penyebab kemiskinan;

2. Dampak lingkungan sosial pada lingkungan sosial masyarakat Indonesia, pekerja anak dianggap sebagai sarana yang positif buat mengenal kan kedisiplinan dan menanamkan etika profesional pada anak;

3. Motivasi pekerja dan keluarga. Anak-anak hendaknya tidak cu ku p u mur untuk memikul tanggung jawab atas pekerjaan dan su mbangan kepada keluarga. Selain faktor ekonomi, hal lain yang mempengaruhi pekerjaan anak adalah keluarga itu sendiri, keluarga merupakan unit ekonomi atau konsu men dan dipengaruhi oleh kondisi ekstemal dan intemal termasuk menentukan ju mlah pekerjaan yang dilakukan.

Perlindungan hukum anak bisa diartikan sebagai usaha perlindungan hukum dalam arti beragam kebebasan dan hak asasi anak serta beragam manfaat yang terkait dengan kesejahteraan. Oleh karena itu, perlindungan hukum terhadap anak mencakup cakupan yang sangat luas, antara lain:

a. perlindungan terhadap kebebasan anak;

b. Perlindungan terhadap hak asasi anak;

c. Perlindungan hukum terhadap semua kepentingan anak yang berkaitan dengan kesejahteraan.

Beberapa ahli mengklasifikasikan dampak eksploitasi seksual komersial anak menjadi beberapa jenis, yaitu:

- Gangguan stres pasca trauma (PTSD) Anak-anak yang pemah atau telah dieksploitasi secara seksual barangkali mengalami kecemasan, stres, atau ketakutan yang parah. Gejala ini disebut gangguan stres pasca trauma (PTSD);

- Penyalahgunaan narkoba Anak-anak yang pemah dieksploitasi secara seksual atau dieksploitasi secara seksual dapat menggunakan alkohol atau zat lain untuk menenangkan emosi mereka. Beberapa korban mengonsumsi narkoba untuk menghadapi kenyataan tentang apa yang terjadi kepada mereka, atau untuk menangani gejala gangguan stres pascatrauma, yang merupakan respond umum terhadap situasi ekstrim seperti kekerasan seksual;

- Depresi ini adalah suatu reaksi emotional dan psikologis yang paling umum dari seorang anak yang dieksploitasi secara seksual atau dieksploitasi secara seksual dalam waktu yang lama untuk berdu ka dan menangis.

Dan gejala lainnya, seperti:

1. Satu Penurunan berat badan bisa menyebabkan perubahan nafsu makan;

2. Kehilangan tenaga atau kelelahan atau kelesuan yang konstan; 
3. Peru bahan pola tidur yang signifikan (insomnia, tidur berlebihan, tidur gelisah);

4. Kehilangan minat dan kesenangan dalam aktivitas yang sebelumnya disukai, penarikan sosial, perasaan tidak ber harga, putus asa atau rasa bersalah yang tidak pantas, pesimisme atau ketidakpedulian;

5. Nyeri (sakit kepala, sakit perut);

6. Tidak bisa berkonsentrasi;

7. Lekas marah, khawatir, marah, gernbira atau cemas.

Segala bentuk perilaku akan sangat merusak hak anak untuk menikmati masa remaja dan kemarnpuannya untuk menjalani kehidupan yang produktif. Memberikan layman rehabilitasi bagi anak korban eksploitasi seksual yaitu proses yang kornpleks dan sulit. Orang yang dieksploitasi biasanya merasa malu, harga diri dan harga diri rendah. Perlindungan hukum pada anak merupakan upaya yang dapat dilakukan oleh berbagai lapisan masyarakat untuk melindungi generasi bangsa dan melindungi hak yang mutlak seharusnya dimiliki oleh anak (Mahadewi et al., 2021).

Dalam hukum Islam dikenal konsep Maqasid Asi Shariah (Arb al-maqasid, artinya target). Imam asy-syaitibi (Ahli Hukum Mazhab Maliki) mengatakan bahwa dalam mewujudkan kepentingan dunia dan seterusnya ada lima hal yang harus dipegang tegu h. Berlandaskan hasil anjuran ulama terhadap berbagai teks, lima yaitu agama, jiwa, pemikiran, garis keturunan, dan harta (Muzakki, 2013). Keturunan merupakan dakwah Allah SWT dan harus dipertahankan. Terlepas dari posisinya, ia percaya bahwa kodrat, martabat, dan hak manusia harus dijaga. Harus dipastikan bahwa anak tumbuh dan berkembang sesuai dengan martabatnya. Oleh karena itu, kita harus segera menghentikan segala bentuk kekerasan, pelecehan, penelantaran, diskriminasi dan eksploitasi tidak manusiawi yang melanggar dan merongrong hak anak dan perempuan, termasu k eksploitasi untuk tujuan komersial.

Mengenai keamanan korban eksploitasi seksual, dalam konsep Maqashid Asi Shariah telah dijelaskan bahwa dalam Islam kita hidup untuk tujuan hukum Shariah, dan kita sebagai manusia harus menjaga. generasi dan properti masa depan. Islam telah menjelaskan untuk menjaga generasi yang akan datang agar tidak menyia-nyiakan mereka, tidak berhnhong, tidak berzina. Islam menetapkan bahwa peraturan ini akan menjadi hak anak, dan anak akan menangis karena penghinaan, jika tidak maka ia akan ditinggalkan. Bagi orang tua, memberikan pertumbu han yang sempuma adalah tugas yang berat. Kewajiban ini yaitu tugas yang diharuskan oleh hukum agama dan masyarakat, oleh karena itu banyak orang tua yang tidak mau menjaga pertumbuhan anak-anak mereka, dan orang tua ini tidak bertanggung jawab atas misi Tuhan dan hukum.

Dalam Alquran ada 15 ayat 23 sampai 24. Ketika menjelaskan ayat ini, analisisnya adalah bahwa orang tua memiliki kewajiban untuk memperlakukan anaknya dengan baik, dan kemudian anak memiliki kewajiban untuk berbuat baik kepada anaknya. orangtua. Surat Anisa ayat 4, ayat 9, isi ayat tersebut menginstruksikan kita untuk khawatir meninggalkan keturunan yang lemah. Fisik, mental, ekonomi, kesehatan, intelektual, dan moral semuanya lemah. Ayat ini menyampaikan pesan bahwa kita melindungi anak cucu kita, bahkan mereka yang belum lahir lebih awal pun tidak akan lahir tidak sehat, tidak bijaksana, kurang gizi dan terlantar.

Islam dimaknai sebagai pedoman menopang keturunan agar tidak disia-siakan, ditipu dan dipalsukan. Islam menetapkan bahwa peraturan ini akan menjadi hak anak, dan anak akan menangis karena penghinaan, jika tidak maka ia akan menderita bencana karena ditelantarkan. Bagi anak-anak, pertumbuhan yang sempuma adalah tugas yang sulit baik bagi ibu maupun ayah. Kewajiban ini merupakan kewajiban yang ditekankan oleh hukum agama dan kemasyarakatan, sehingga banyak orang yang enggan memperhatikan pengasuhan anak, mereka menganggap mereka sebagai orang tua yang tidak bertanggung jawab kepada Tuhan dan kewenangan hukum.

Sanksi hukuman yang dijatuhkan kepada suatu negara atau suatu kelompok atas kejahatan yang dilakukan oleh seseorang atau suatu kelompok. Sanksi pidana adalah hukuman yang paling banyak digunakan untuk menghukum terpidana kejahatan (Ali, 2013). Sebagaimana kita ketahui bersama, Islam adalah hukum agama yang menjamin, melindungi dan menjaga kepentingan umat manusia dalam bentu $\mathrm{k}$ perintah atau larangan yang mengikat yang harus ditaati 
oleh masyarakat. Pasal 14 ayat (1), Pasal 81 dan Pasal 82 UU No. 35 tahun 2014 secara jelas mengatur sanksi hukum bagi pelanggar yang melakukan eksploitasi seksual terhadap anak, kemudian dipidana dengan pidana kurungan paling lama 15 (lima belas) tahun dan minimal 3 (tiga) tahun. Denda paling banyak Rp 300.000.000,00 (tiga ratus juta rupiah) dan denda paling banyak Rp 60.000.000,00 (60 juta rupiah). Hukuman tidak hanya berlaku bagi pelaku kejahatan seksual, tetapi Pasal 88 juga menjelaskan mereka yang berburu keuntungan bagi diri sendiri atau orang lain. UU terhadap pelaku hanya mencakup pidana pokok yaitu pidana penjara dan denda. Dari segi tujuan hukuman, baik hukum aktual maupun hukum Islam menegaskan bahwa hukuman dimaksudkan untuk memberikan pencegahan dan pembalasan bagi pelaku tindak pidana eksploitasi seksual. Inti dari pemajuan martabat manusia, khususnya penghukuman terhadap perempuan dan anak korban eksploitasi seksual, adalah prostitusi.

\section{SIMPULAN DAN SARAN}

\section{Simpulan}

Berdasarkan hasil pembahasan masalah-masalah yang dibahas dalam penelitian terkait, maka dapat ditarik kesimpulan sebagai berikut:

1. Hukum Islam menjatuhkan sanksi kepada arima, dan Alquran tidak menjelaskan sanksi tersebut bersama dengan Tazier. Ketentuan ta'zir merupakan kewenangan ulil amri (hakim), dalam hal ini hakim menetapkan hukuman bagi pelaku eksploitasi seksual sesu ai dengan Pasal 88 Undang-Undang Nomor 8. Dari sisi kerugian yang dialami oleh para korban, Peraturan No. 45 Tahun 2014 tentang Perlindungan Anak kurang tepat karena langkah konkrit yang harus diambil untuk memulihkan anak secara fisik, psikologis dan sosial.

2. perbuatan eksploitasi seksual tidak memiliki makna khusus, tetapi perbuatan eksploitasi seksual termasu $\mathrm{k}$ dalam perbuatan zina karena mengandung tujuan eksploitasi seksual, yaitu prostitusi. Pada saat yang sama, eksploitasi seksual di bawah Undang-Undang Perlindungan Anak mengacu pada eksploitasi, eksploitasi atau pemerasan terhadap anak di bawah usia 18 tahun yang dipekerjakan sebagai pekerja seks untuk keuntungan pribadi, keluarga atau kel ornpok.

\section{Saran}

Saran penulis berkaitan dengan pembahasan inasalah yang dibahas dalam penelitian ini, seperti gambar dibawah ini:

1. Mengharapkan orang tua lebih menghargai hak dan kewajiban anak, karena anak adalah domain orang tua dan anaknya.

2. Masyarakat perlu dididik untuk mencegah eksploitasi seksual terhadap anak.

3. Pemerintah harus memberikan efek jera kepada pelaku eksploitasi seksual anak dan mengenakan denda tarnbahan.

\section{DAFTAR PUSTAKA}

Ali, M. (2013). Asas-asas hukum pidana korporasi (Cet.1). Raja Grafindo Persada, Jakarta.

Ariyadi. (2019). Tindak Pidana Pelaku Eksploitasi Seksual Pada Anak Menurut Hukum Islam. Jurnal Hadratul Madaniyah, Vol.6(1).

Arliman, L. (2017). Reformasi Penegakan Hukum Kekerasan Seksual Terhadap Anak Sebagai Bentuk Perlindungan Anak Berkelanjutan. Jurnal Ilmu Hukum Kanun, Vol.19(2).

Firmansyah, R., \& DasukiSuhardini, E. (2017). Perlindungan Hukum Terhadap Anak Korban Eksploitasi Seksual dan Perdagangan Orang Berdasarkan Undang-Undang Nomor 21 Tahun 2007 tentang Pemberantasan Tindak Pidana Perdagangan Orang. Jurnal Ilmu Hukum Wacana Paramarta, Vol.16(3).

Mahadewi, K., Rindeng, I. W., \& Widiati, I. A. P. (2021). Perlindungan Hukum Terhadap Anak Sebagai Pelaku Tindak Pidana dari Perspektif Kemerdekaan Pers. Jurnal Konstruksi Hukum, Vol.2(2).

Motosoedirdjo, M., \& Latipun. (2019). Kesehatan Mental (Cet.2 (ed.)). UMM Press, Malang.

Muzakki, A. (2013). Reformasi Pendidikan Holistik Islam di Indonesia. Idea Publishing House, Yogyakarta. 
Permatasari, E. (2016). Perlindungan Terhadap Anak Korban Eksploitasi Seksual dalam Perspektif YuridisNormatif dan Psikologis (Studi Kasus Wilayah Hukum Polres Lampung Timur). AL-'ADALAH, Vol.13(2).

Saraswati, R. (2015). Hukum Perlindungan Anak di Indonesia,. PT Citra Aditya Bakti, Bandung.

Soeaidy, S., \& Zulkhair. (2001). Dasar hukum perlindungan anak : anak cacat, anak terlantar, anak kurang mampu, pengangkatan anak, pengadilan anak, pekerja anak. Novindo Puastaka Mandiri,Jakarta. 